\title{
Understanding the impact of droughts in the Yarmouk Basin, Jordan: monitoring droughts through meteorological and hydrological drought indices
}

\author{
Alsharifa Hind Mohammad ${ }^{1} \cdot$ Hahn Chul Jung ${ }^{2,3} \cdot{\text { Taleb } \text { Odeh }^{4} \cdot \text { Chandrashekhar Bhuiyan }^{5} \cdot \text { Hussam Hussein }}^{6,7}$ (I)
}

Received: 25 October 2017 / Accepted: 7 February 2018 / Published online: 7 March 2018

(C) The Author(s) 2018. This article is an open access publication

\begin{abstract}
This article assesses drought status in the Yarmouk Basin (YB), in northern Jordan, using the Standardized Precipitation Index (SPI), the Standardized Water-Level Index (SWI), and the Percent Departure from Normal rainfall (PDNimd) during the years 1993-2014. The results showed that the YB suffers from frequent and irregular periods of drought as variations in drought intensity and frequency have been observed. The SPI results revealed that the highest drought magnitude of -2.34 appeared at Nuaimeh rainfall station in 1991. This station has also experienced severe drought particularly in years 1995, 1999, 2005, and 2012 with SPI values ranging from -1.51 to -1.59 . Some other rainfall stations such as Baqura, Ibbin, Khanasiri, Kharja, Mafraq police, Ramtha, Turra, and Umm Qais have also suffered several periods of drought mostly in 1993. The SWI results show the highest extreme drought events in 2001 in Souf well while other extreme drought periods were observed at Wadi Elyabis well in 1994 and at Mafraq well in 1995. As compared to SPI maps, our SWI maps reflect severe and extreme drought events in most years, negatively impacting the groundwater levels in the study area.
\end{abstract}

Keywords Drought $\cdot$ SPI $\cdot$ PDN $\cdot$ SWI $\cdot$ GIS $\cdot$ Yarmouk Basin $\cdot$ Jordan

\section{Introduction}

Jordan is among the most water scarce countries in the world. Droughts have an impact on the quantity of the precipitations,

Hussam Hussein

h.hussein@uea.ac.uk

1 Water, Energy and Environment Center, The University of Jordan, Amman, Jordan

2 Hydrological Sciences Laboratory, NASA Goddard Space Flight Center, Greenbelt, MD, USA

3 Science Systems and Applications, Inc. (SSAI), Lanham, MD, USA

4 Prince Al Hassan Bin Talal Faculty of Arid Land, The Hashemite University, Zarqa, Jordan

5 Department of Civil Engineering, Sikkim Manipal Institute of Technology, Sikkim Manipal University, Majhitar, Sikkim, India

6 School of International Development, University of East Anglia (UEA), Norwich Research Park, Norwich NR4 7TJ, UK

7 Issam Fares Institute for Public Policy and International Affairs, American University of Beirut (AUB), Beirut, Lebanon on the groundwater recharge, and on their quality. Jordan as many other countries in the world faces serious problems related to water shortages, which negatively affect its entire development (Jasem and Raggad 2010; Mohammad et al. 2015; Hussein 2018a). Hence, droughts are having a direct impact on increasing the water insecurity. Recent research showed that the Jordanian government has been exploring several solutions to increase the water supply in the country in the past decades, from building the Wahda Dam, the Disi Canal project completed in 2013, and supporting the construction of the Red Sea-Dead Sea Canal (Hussein 2017a, 2017b, 2017c; 2018b). However, it is necessary to provide policymakers with clear and detailed data concerning the impact of droughts, so that policy measures - informed by academic and scientific evidence - can be taken. Hence, this article assesses the droughts status in the Yarmouk Basin (YB) in the 1993-2014 period.

Being among the most water scarce countries in the world, Jordan has an acute water crisis also as results of limited water resources, water quality deterioration, increasing water demand due to a rapidly growing population, and due to an overall mismanagement of water resources - especially in 
the agricultural sector (Salameh and Bannayan 1993; Hussein 2016; Yorke 2016; Haddadin 2006). However, water drought further increased the water crisis in Jordan and therefore this article argues that it is necessary to monitor droughts' impacts on groundwater resources in northern Jordan. Therefore, this article contributes to the literature by evaluating the water drought and its effects on the water resources in the YB.

Drought is an environmental phenomenon that is associated with a deficit of water resources in a specific region for a significant period of time (Rossi 2000). Drought is not limited to arid climatic conditions; it might occur in areas with both high and low rainfall rates. There are several drought indices for drought monitoring, which allow decision-makers to identify abnormal weather conditions for a region (Wilhite et al. 2000).

Droughts have many direct and indirect effects on different sectors; water resources and natural systemssuch as the agricultural and environmental settings - are directly impacted, while droughts affect indirectly the socio-economic sector, which is strongly dependent on the natural system. Thus, several indices and methods have been applied to model drought in different parameters such as rainfall, temperature, soil moisture, and vegetation index (Palmer 1965, 1968; Shafer and Dezman 1982; Kogan 1990; McKee et al. 1993).

Droughts vary significantly among regions of various climatic conditions (Dracup et al. 1980). Generally, the rainfall is directly affecting droughts; and soil moisture, stream flow, dam storage, and groundwater level are the main consequences of the rainfall drought (Umran Komuscu 1999).

However, Bhuiyan (2004) found that the drought measuring parameters are not linearly related to one another. In fact, he showed that it is common that when one drought index identifies drought in a particular place, another drought index may indicate a normal condition at the same place and time (Bhuiyan 2004).

The YB in the north-western part of Jordan is a key area on the hydrological map of the country: the highest amounts of rainfall are received there; wide areas of rain-fed agricultural patterns are situated in the YB; and part of the Jordanian forest, which is very important for the biodiversity, is located within the basin. The YB has different topographical units, and accordingly, the elevation above sea levels vary from about -213 to $1176 \mathrm{~m}$. These units generated the rainfall pattern that affects the spatial distribution of the ecological and land cover units.

In this study, time series drought maps of the YB have been collected through a geographic information system (GIS) method using various drought indices. Three indices have been modeled; the Standardized Precipitation Index (SPI) and the percentage departure from normal rainfall $(\mathrm{PDN})$ have been used to monitor meteorological drought; and Standardized Water-Level Index (SWI) was developed (Bhuiyan 2004; Bhuiyan et al. 2006) to analyze hydrological drought and to assess groundwater recharge deficit.

Changing the quantities of precipitation over a specific area is an important parameter for evaluating climatic changes (Holman 2006). This has also a direct impact on the groundwater level, specifically through monitoring the infiltration in the water balance equation (Holman 2006; Jones et al. 2005). In the studied area, groundwater is the major water resource for drinking water and for irrigation (Hussein and Grandi 2015, 2017). However, droughts increase pumping groundwater resources to meet the demand, putting additional pressure on the groundwater resources. Hence, the groundwater level would decrease too. Accordingly, the second objective of this research is to evaluate drought control on the groundwater and vegetation cover.

\section{Study area}

The YB is a transboundary water basin shared between Jordan and Syria. Only 1424 square kilometers $\left(\mathrm{km}^{2}\right)$ of the basin total area $\left(7242 \mathrm{~km}^{2}\right)$ lies within the Jordanian territory (Awawdeh and Jaradat 2010). The Yarmouk Basin in Jordan has an area of about $1160 \mathrm{~km}^{2}$, of which more than $50 \%$ is covered by vegetation that is irrigated by the available water resources in the catchment, mainly groundwater. Therefore, the droughts here put pressure on a key resource: groundwater resources. In Jordan, this basin is hydrologically important: the adjacent mountain areas and heights (Ajlun Mountains and Jolan Heights( that stand at $1200 \mathrm{~m}$ above sea level are the highest uplands to the east of the Jordan Rift Valley; and these areas receive the highest rainfall in the country. In addition, the Yarmouk River flows between Syria and Jordan, delineating the northern boundary of the study area (Fig. 1, which adopts the coordinates system in Transverse Mercator, Palestine 1923 Palestine Belt).

\section{Methodology}

An important method deployed in this research was the geographic information system (GIS), which is a key tool to produce thematic maps. Those maps are used to understand the spatial distribution of natural phenomena such as water drought (Kam 1995). Creating a geodatabase for the rainfall stations located in the study area was the first step to start modeling the drought there; and the attributes of this geodatabase were the parameters that the climate stations measured. The thematic maps were generated by interpolations of the estimated drought index for each station. The software ArcGIS 10.3 has been used for producing the geodatabase, 


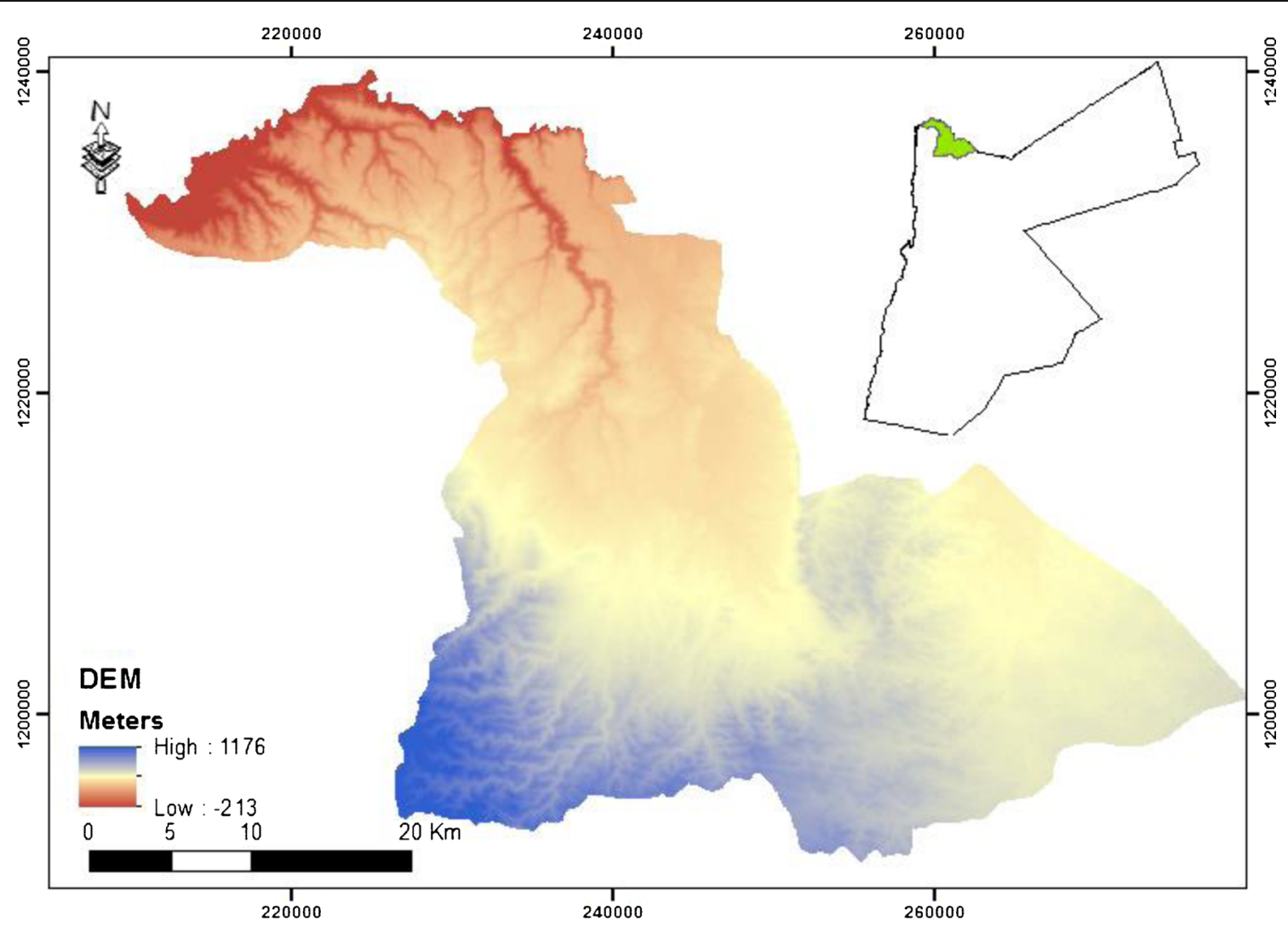

Fig. 1 Location of the Yarmouk River Basin and elevation map of the study area

while the spatial analyst extension was used to carry out the interpolation by kriging method. Kriging is an optimal interpolation based on regression against observed " $z$ " values of surrounding data points, weighted according to spatial covariance values (Bohling 2005). All point maps annual rainfall records from the rain gauge stations, and annual groundwater levels from different monitoring wells all over the targeted area were interpolated using the kriging method in ArcGIS 10.3. The resulted maps were all in raster format, and values for each point were estimated according to its drought index to produce the final maps.

Extensive literature has researched the drought evaluation by using different indices, models, and water balance simulations (Jain et al. 2010). There are several indices for drought monitoring, including Palmer Drought Severity Index (PDSI), Crop Moisture Index (CMI), Surface Water Supply Index (SWSI), Percent of Normal Index (PN), and Standardized Precipitation Index (SPI) (Mishra and Singh 2010). In this study, both meteorological and hydrological drought indices were applied to measure the drought. So, given the scope and aim of this research, the following meteorological indices have been deployed: Standardized Precipitation Index (SPI), Percent Departure from Normal rainfall (PDNimd), and Standardized Water-Level Index (SWI). These indices have been chosen because of the data needed to answer the guiding question, because they are the most appropriate compared to the limited other indices options available and because the availability of the needed data for long period of time which will reflect high accuracy of the work. In addition, these indices allowed methodological triangulation and, therefore looking at the same phenomenon from different perspectives, allowed rigorous capturing of the phenomenon of droughts in the YB.

\section{Standardized Precipitation Index}

SPI is a widely accepted and used index for meteorological drought monitoring, (Shamsnia et al. 2009). This index focuses on the precipitation as the major element of the water cycle. This index looks at precipitation as the most effective

Table 1 SPI classification scheme (McKee et al. 1993)

\begin{tabular}{cl}
\hline SPI range & Drought intensity class \\
\hline $2.00 \geq$ & Extremely wet \\
$1.50 \sim 1.99$ & Very wet \\
$1.00 \sim 1.49$ & Moderately wet \\
$0.99 \sim-0.99$ & Near normal \\
$-1.00 \sim-1.49$ & Moderately dry \\
$-1.50 \sim-1.99$ & Severely dry \\
$\leq-2.00$ & Extremely dry \\
\hline
\end{tabular}




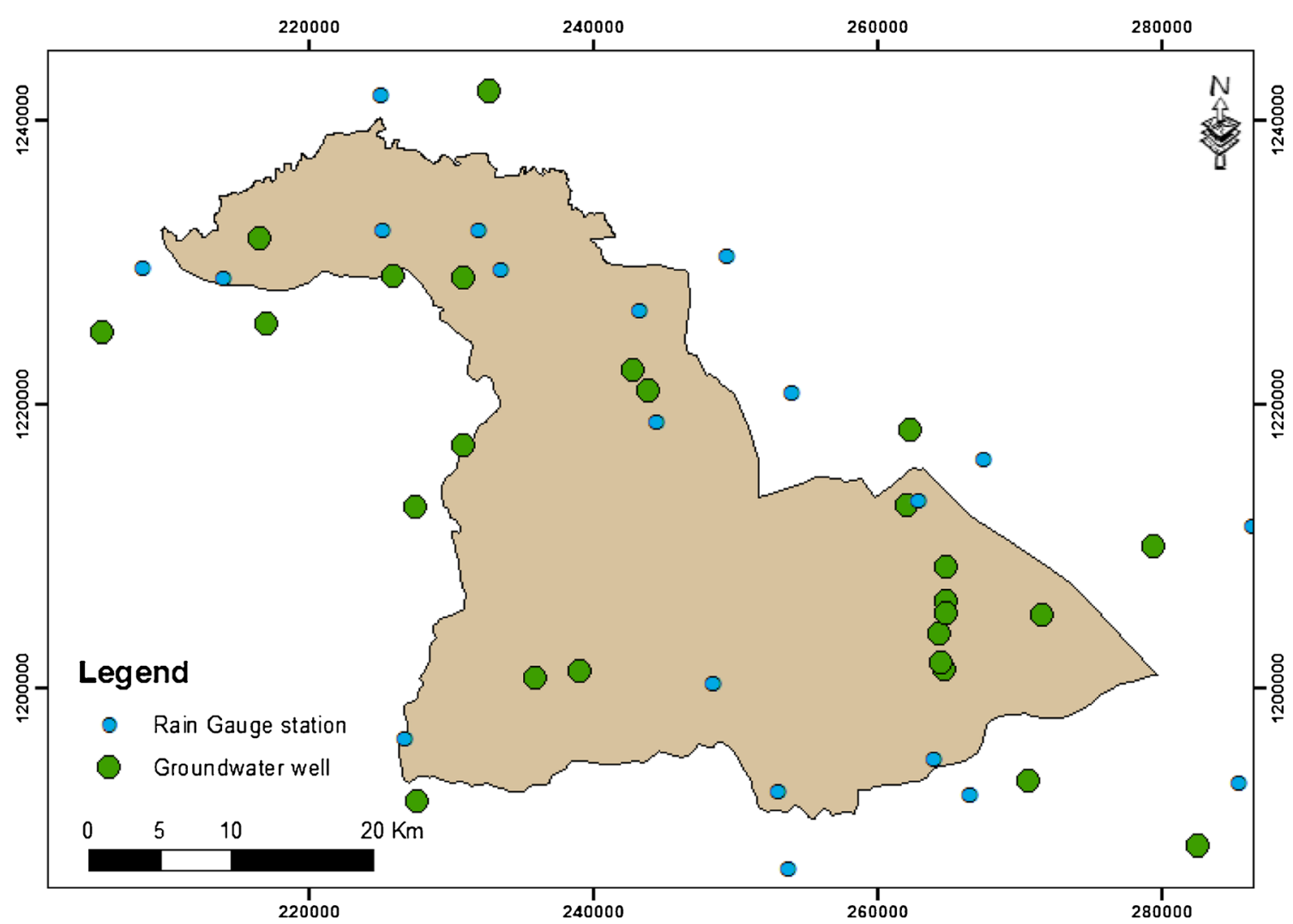

Fig. 2 Rainfall gauge stations and groundwater wells in and around the Yarmouk Basin

parameter in the calculation of the drought severity. SPI is normally distributed spatially so it can be applied to monitor wet and dry periods. Al-Dardoor et al. (2013) assessed the drought in YB using vegetation indices which use the satellite images to analyze the percentage of the plant cover within the targeted area.

McKee et al. $(1993,1995)$ proposed SPI to assess anomalous and extreme precipitations. The SPI is based on the probability of precipitation for any desired time scale and spatially invariant indicator of drought (Guttman 1998, 1999). It involves fitting a gamma probability density function to a given frequency distribution of precipitation totals for a station (Edwards and McKee 1997). The equation below presents the modeling of the SPI:

Table 2 Original (IMD 1971) and modified (Bandyopadhyay et al. 2016) PDN classification schemes

\begin{tabular}{lll}
\hline $\begin{array}{l}\text { Rainfall departure } \\
\text { original scheme } \%\end{array}$ & Category & $\begin{array}{l}\text { Rainfall departure } \\
\text { modified scheme } \%\end{array}$ \\
\hline Above $0 \%$ & No drought & Above -10 \\
0 to -25 & Mild drought & -10 to -25 \\
-25 to -50 & Moderated drought & -25 to -50 \\
-50 to -75 & Severe drought & -50 to -60 \\
Below -75 & Extreme drought & Below -60 \\
\hline
\end{tabular}

$\mathrm{SPI}=\frac{\mathrm{Xij}-\mathrm{Xim}}{\sigma}$

where $\mathrm{X}_{\mathrm{ij}}$ is the seasonal precipitation at the ${ }_{\mathrm{i}}$ th rain gauge station and ${ }_{j}$ th observation, $X_{i m}$ is the long-term seasonal mean, and $s$ is its standard deviation. Seven classes of SPI as shown in Table 1 are used in the present study.

In this study, SPI has been used to quantify the precipitation deficit in the rain periods from 1993 to 2014. Monthly rainfall data have been collected from the Ministry of Water and Irrigation (MWI). Therefore, for the computation of SPI, the 21 years mean is calculated using seasonal rainfall data for the wet season in Jordan, which extends from September to March (of available years). The SPI values of the 22 rain gauge stations in and around YB area (Fig. 2) have been interpolated using kriging technique in Arc GIS 10.3 package.

Table 3 SWI classification scheme (Bhuiyan et al. 2006)

\begin{tabular}{ll}
\hline SWI range & Drought intensity class \\
\hline $2.00 \geq$ & Extreme dry \\
$1.50 \sim 1.99$ & Severe dry \\
$1.00 \sim 1.49$ & Moderately dry \\
$0.99 \sim 0.00$ & Mild dry \\
$\leq 0.00$ & Non dry \\
\hline
\end{tabular}




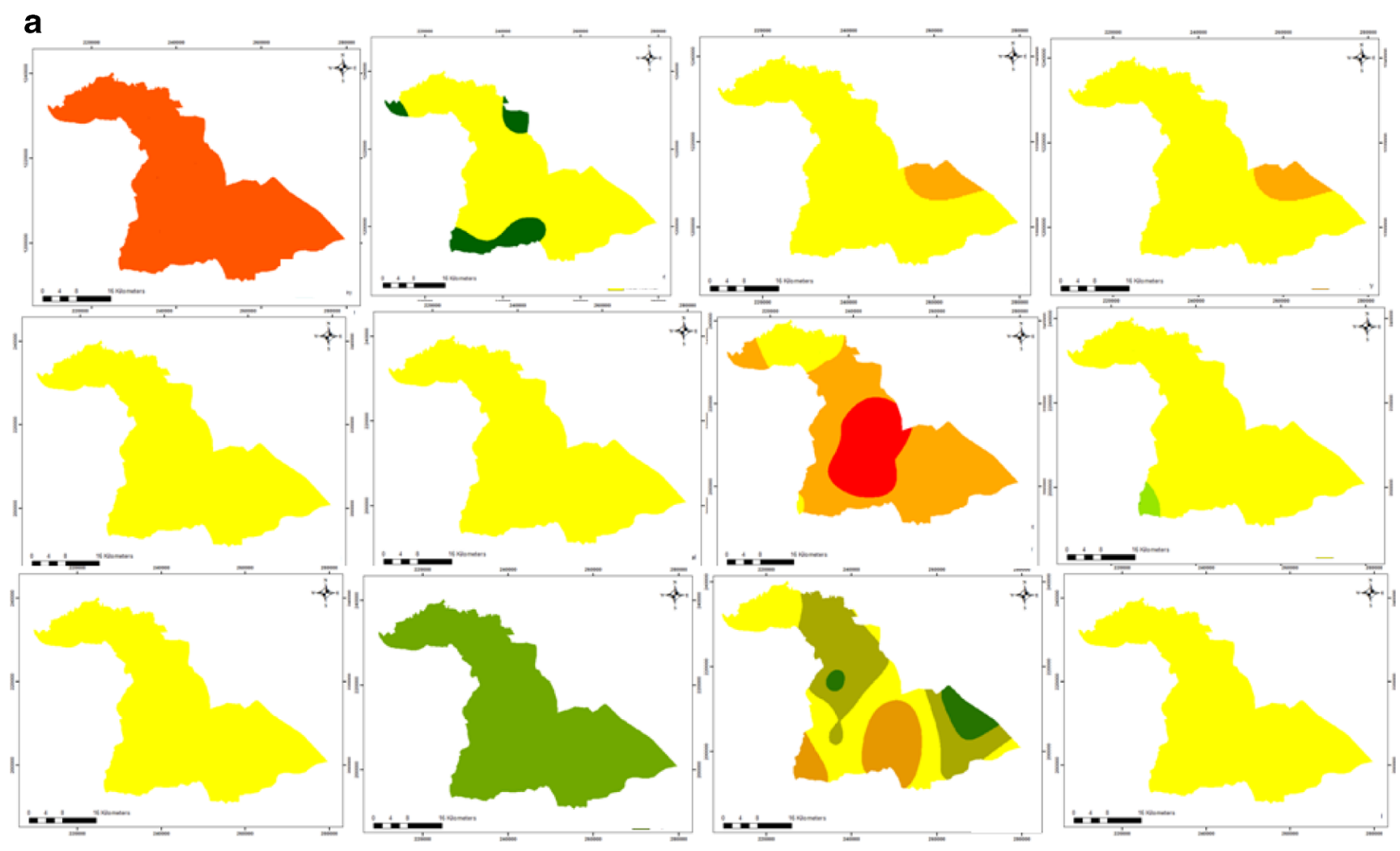

b

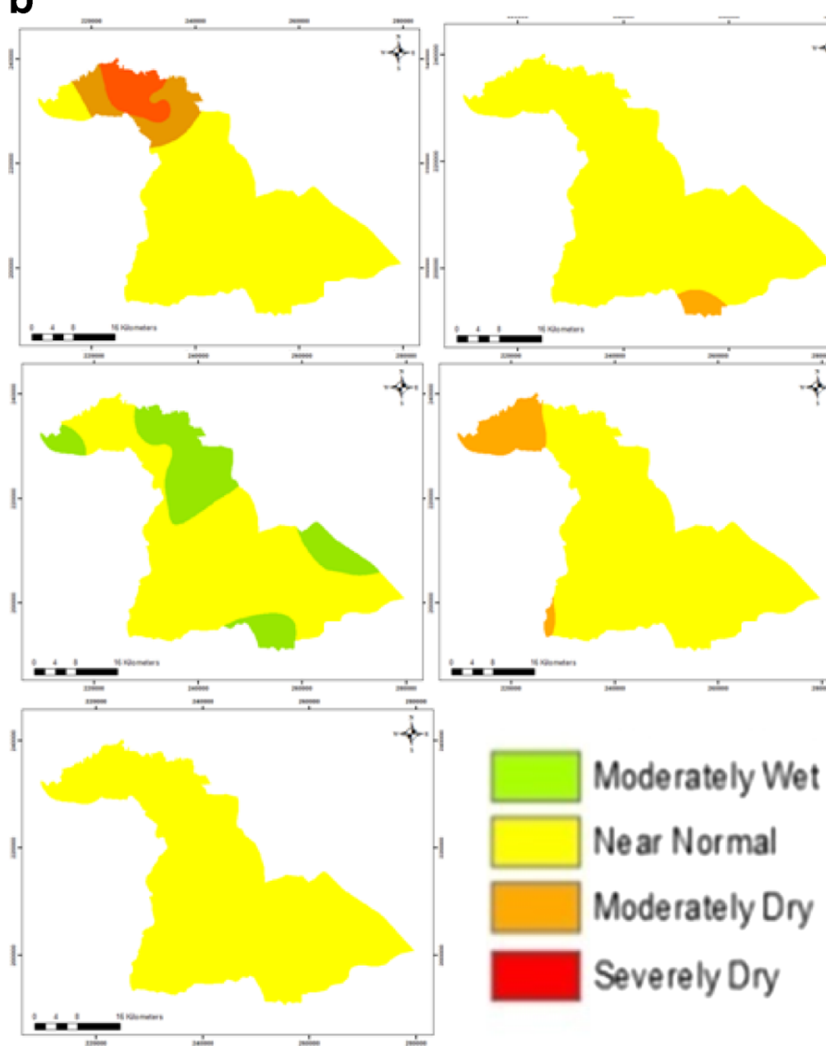

Fig. 3 a Yearly SPI maps from 1993 to 2004, b Yearly SPI maps from 2005 to 2013

Classification of SPI maps has been carried out using the method proposed by McKee et al. (1995) and explained by
Edwards and McKee (1997), to represent various hydrometeorological drought intensities. 
a
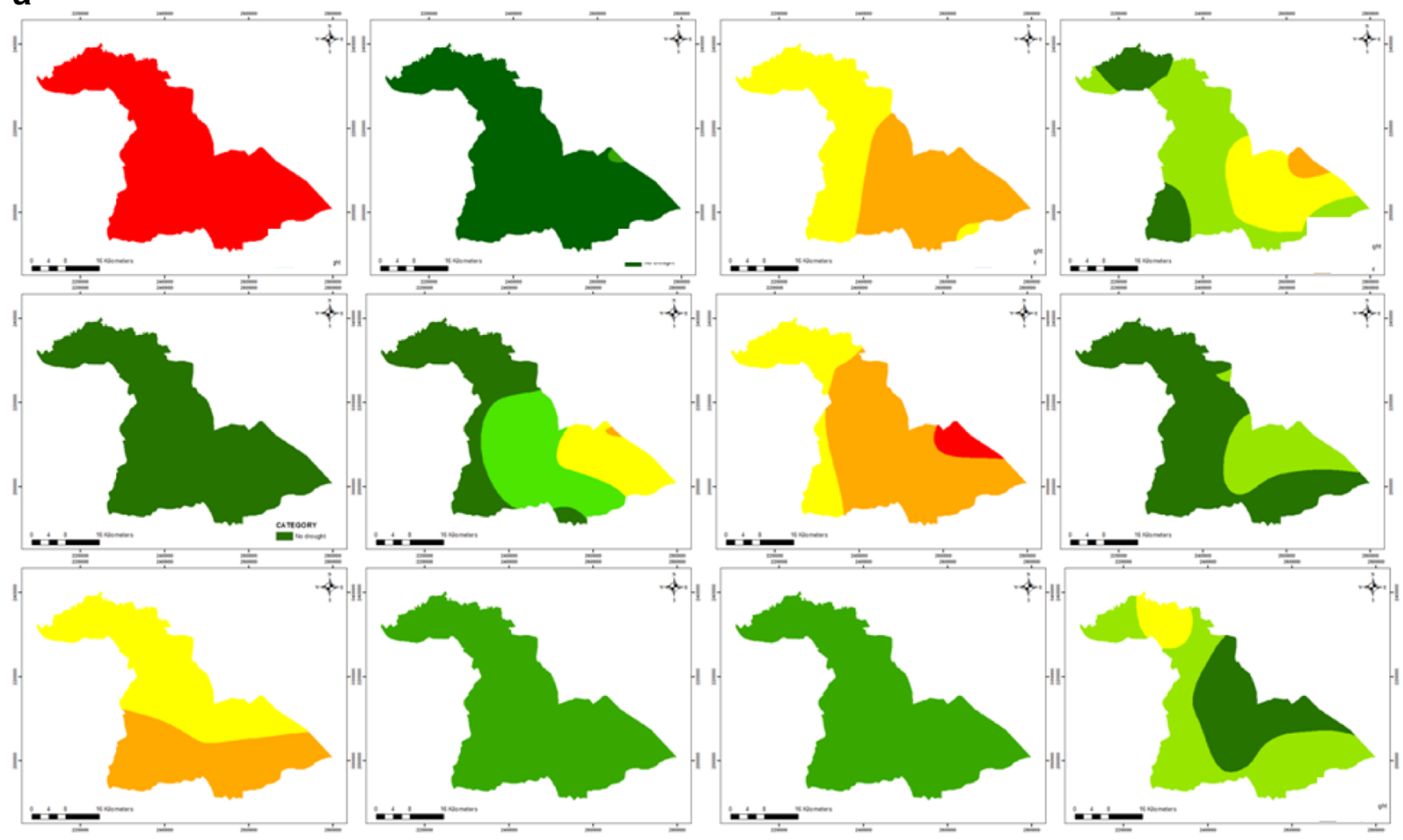

b
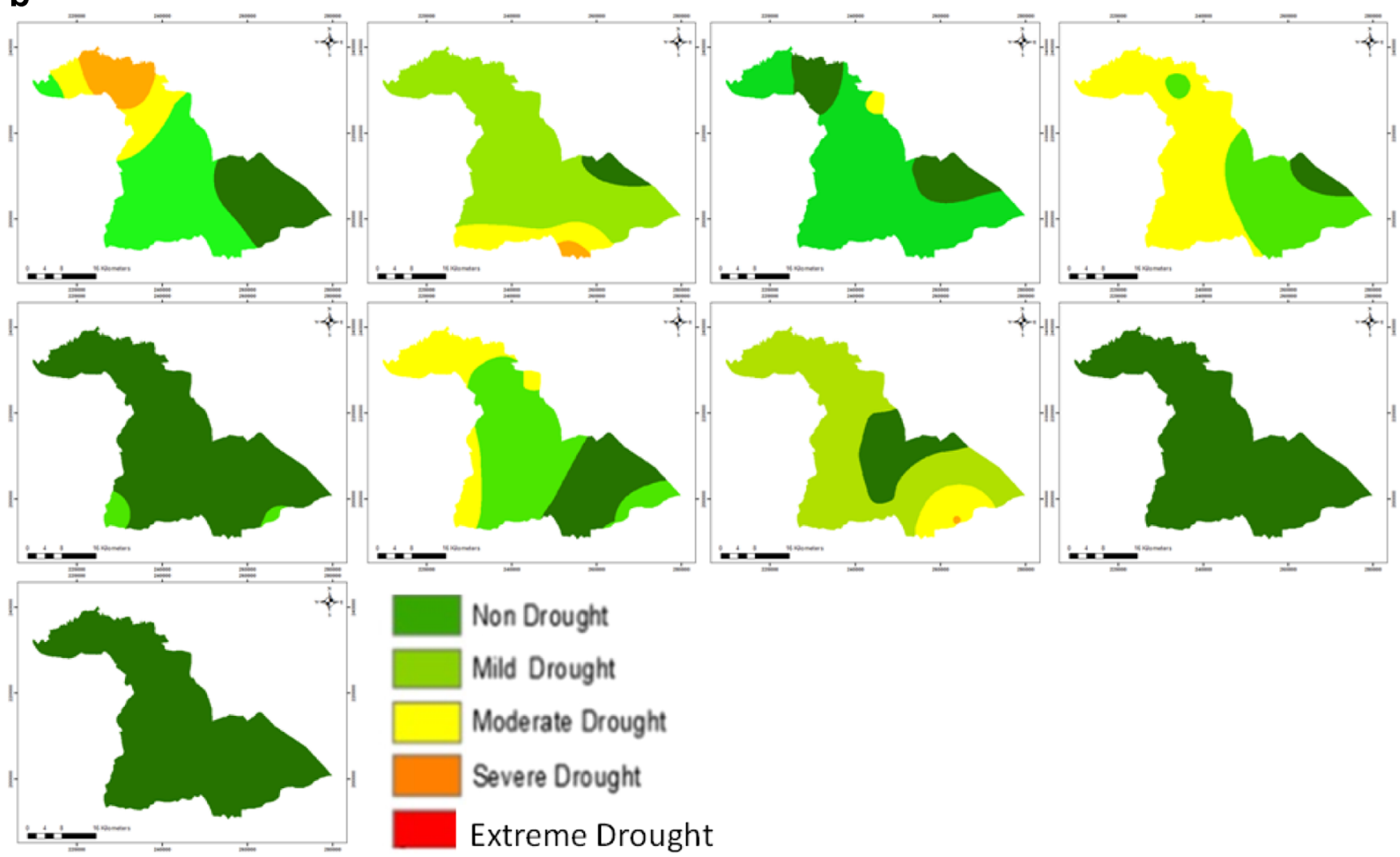

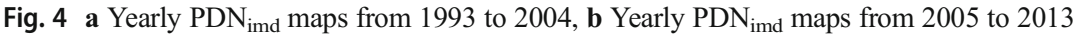




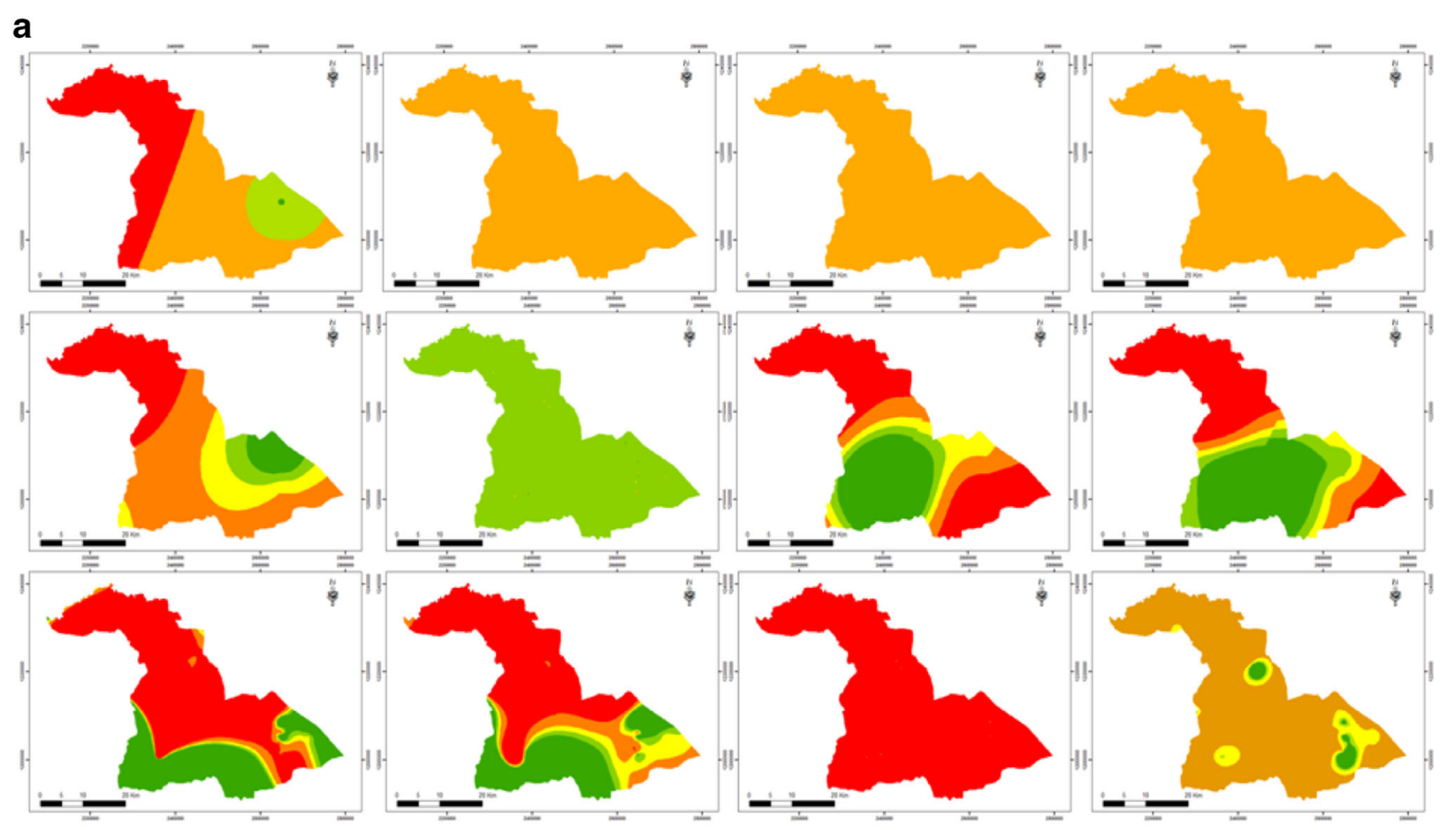

b

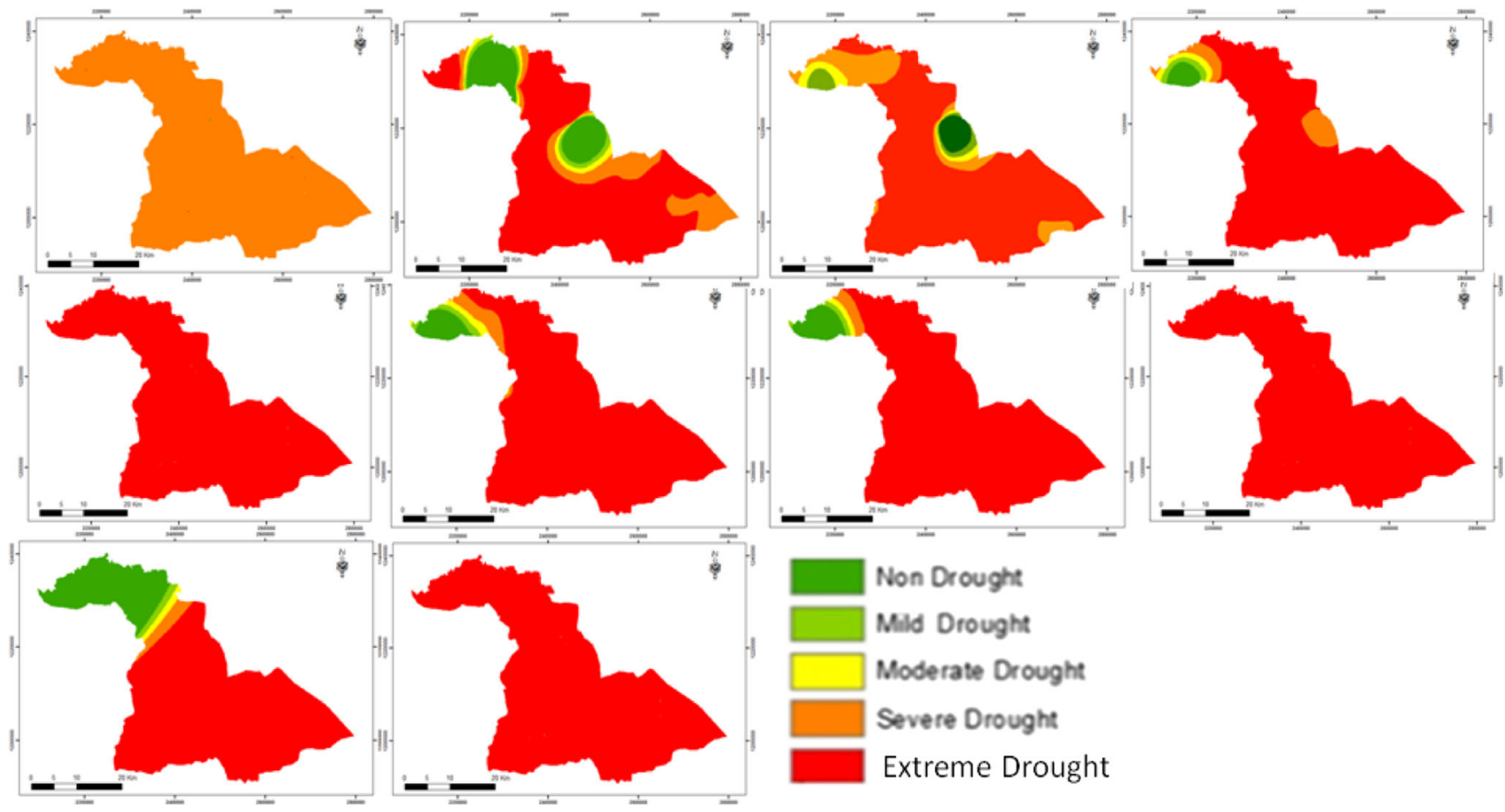

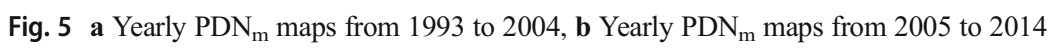

\section{Percent Departure from Normal rainfall}

PDNimd computes the percentage deviation of rainfall from its long-term mean (instead of standard deviation) as follows:

PDNimd $=\left(\frac{P o-\text { long term mean of } P}{\text { long term mean of } P}\right) * \mathbf{1 0 0}$ 


\section{a}

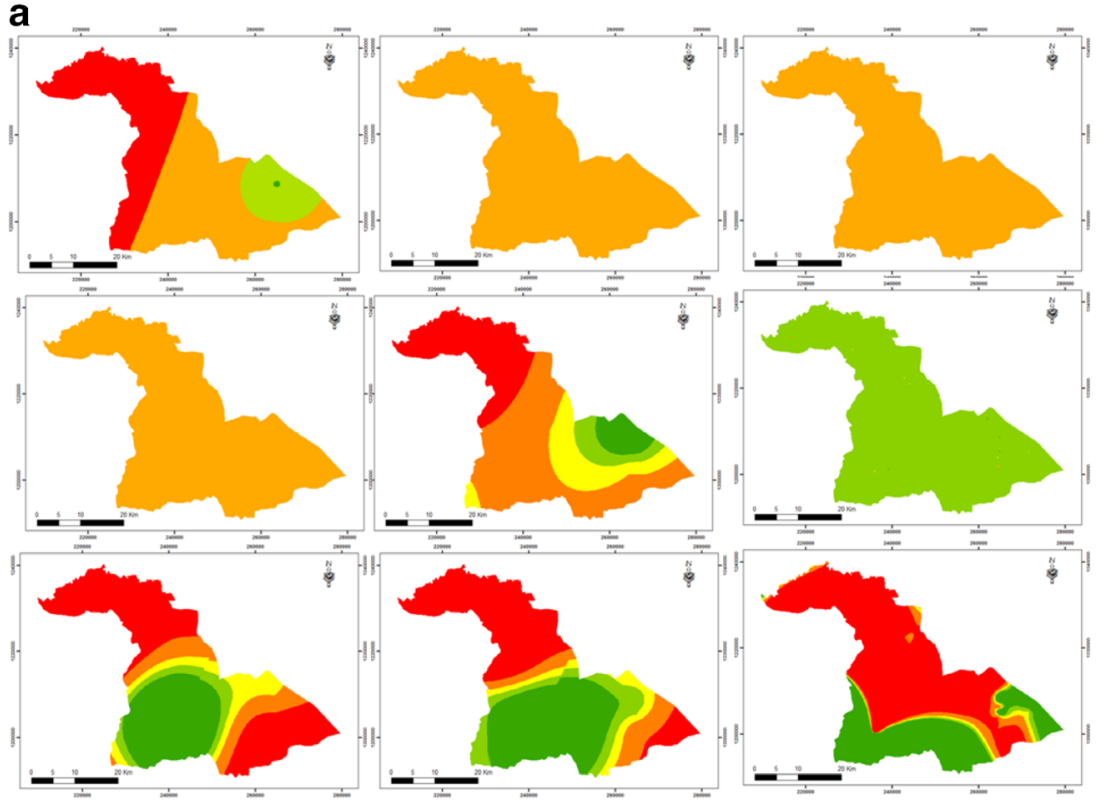

b

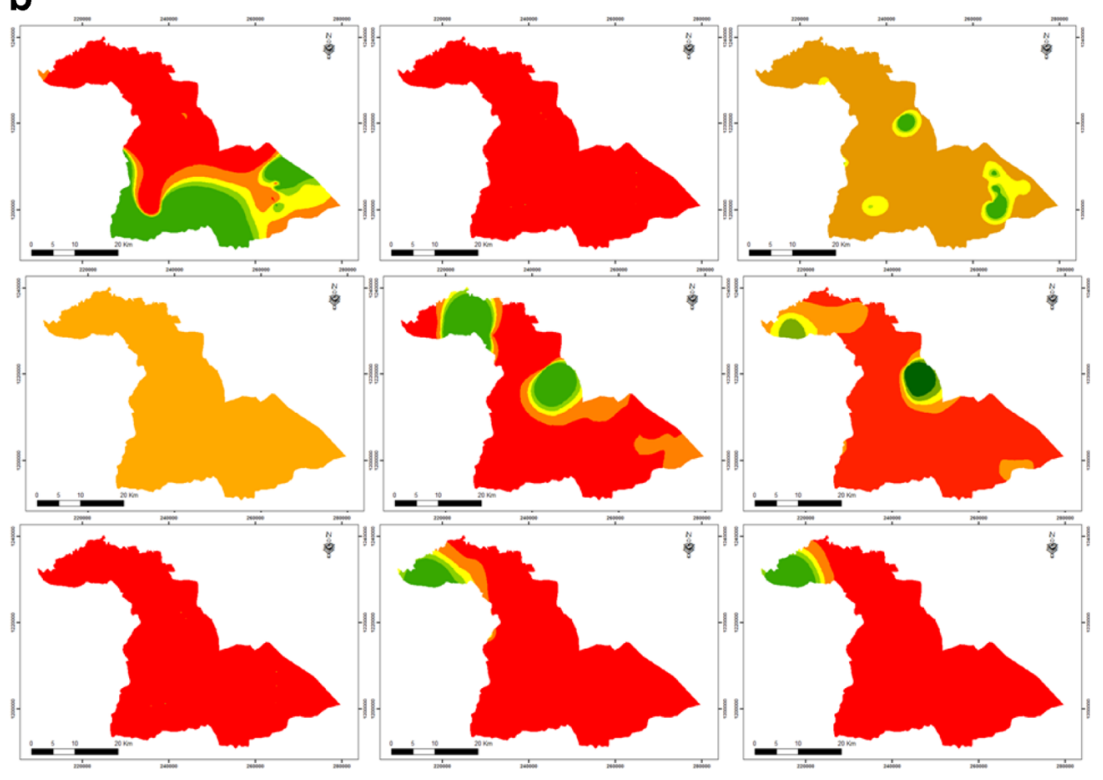

C

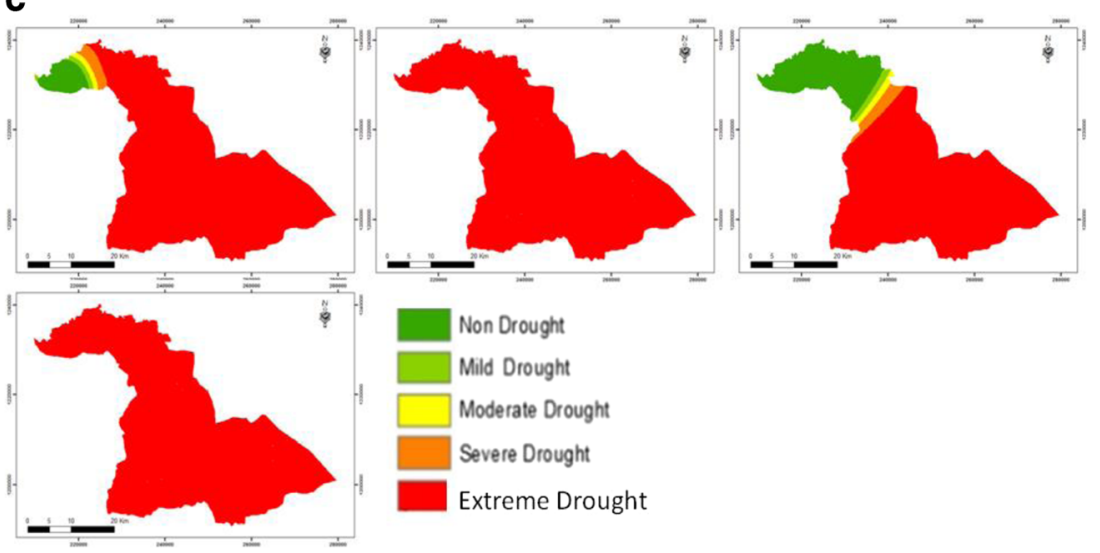

Fig. 6 a Yearly SWI maps from 1993 to 2001, b Yearly SWI maps from 2002 to 2010, c Yearly SWI maps from 2011 to 2014 
Fig. 7 Dry areas \% in different years for both SPI and SWI
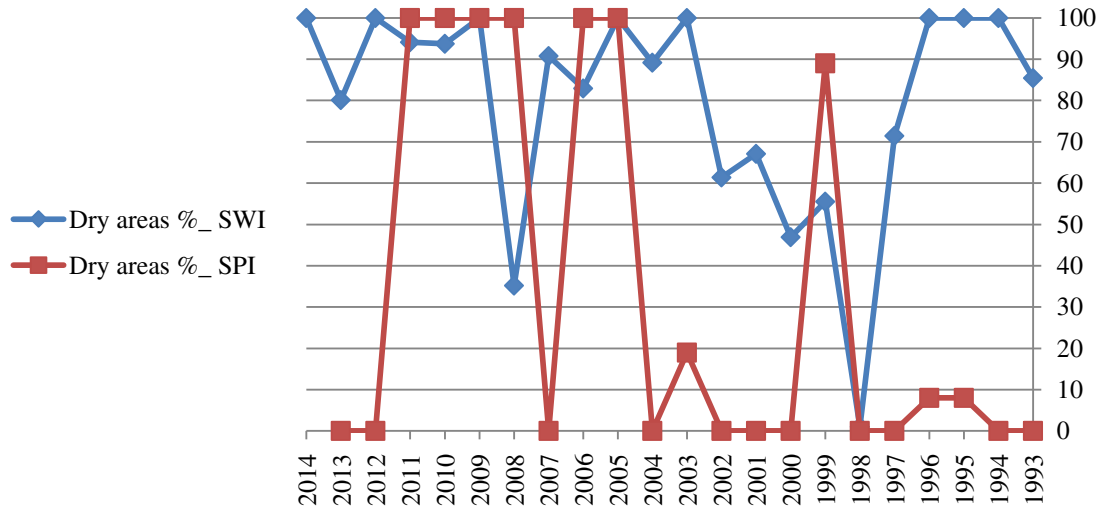

where Po is the observed rainfall at a particular station in a particular duration (month/season/year) and $P$ is the long-term mean rainfall for that station and duration similar to the SPI; the PDNimd index can also be computed for different time scales (monthly, seasonal, annual, multi-year, etc.). Note that, according to the existing PDNimd classification scheme (IMD 1971), drought initiates with rainfall deviation as small as $1 \%$, and "extreme drought" occurs only when rainfall departure is as high as $-75 \%$ from normal. This makes the existing PDNimd classification scheme inefficient, as it provides an unrealistic portrayal of drought. Therefore, the original PDNimd classification scheme (IMD 1971) was modified by Bandyopadhyay et al. (2016) and is used here as PDNm (Table 2). According to PDNm, there is a drought when there is a sudden departure from "normal," but the rainfall is slightly below the long-term mean and is also quite normal, since the mean changes over time with accumulation of more years of data. With this logic, the threshold for mild drought initiation is set at $10 \%$ negative deviation from the mean. In addition, "extreme drought" corresponds to rainfall departure beyond $-60 \%$.

\section{Standardized Water-Level Index}

Bhuiyan (2004) developed the Standard Water-Level Index to monitor anomaly in groundwater level as an effect of the drought on the existing aquifers. The groundwater level data are taken from the MWI for the period of 1993-2014. The SWI according to Bhuiyan (2004) is modeled by normalizing seasonal groundwater level and dividing the difference between the seasonal water level and its long-term seasonal mean, by standard deviation. For normalization, an incomplete gamma function has been used similar to SPI. Thus,

$\mathrm{SWI}=\frac{\mathrm{Wij}-\mathrm{Wim}}{\sigma}$

where $\mathrm{W}_{\mathrm{ij}}$ is the seasonal water level for the ${ }_{\mathrm{i}}$ th well and ${ }_{\mathrm{j}}$ th observation, $\mathrm{W}_{\mathrm{im}}$ is its seasonal mean, and $s$ is its standard deviation. SWI is an indicator of water table decline and an indirect measure of recharge, thus an indirect reference to drought. The original SWI computation (Bhuiyan 2004) involved standardization of the groundwater level data but does not involve normalization. The computation procedure and classification scheme of SWI were modified (Bhuiyan et al. 2006) for drought analysis. The modified SWI computation and classification are similar to the SPI and hence comparable. In this study, the modified SWI classification scheme has been followed (Table 3).

Groundwater levels of 26 wells of the region (Fig. 2) have been collected from MWI and have been analyzed to study the drought effects on hydrological regime. SWI value has been classified and used as a reference to hydrological drought severity (Table 3 ).

SWI has been computed using the mean seasonal water levels of 22 years (1993-2014). SWI values of the wells have been interpolated in a GIS environment to generate SWI maps of the region using similar technique used in SPI.

\section{Results}

\section{Meteorological drought}

\section{Standardized Precipitation Index}

SPI showed that severe to extreme drought occurred in 1993, 1999, and 2005; extremely dry event occurred during 1993 as shown in Fig. 3, which represents the SPI maps for the targeted area within the selected years. Figure 3 also shows that different years show very wet events, starting from 1994, 2000, 2002, and 2003. Near normal events in all rainfall stations within the same year were recorded many times in 1997 , 1998, 2001, 2004, 2007, and 2012 (Fig. 3).

The SPI results revealed that the highest drought magnitude of -2.34 appeared at Nuaimeh rainfall station in 1991 . This station has also experienced severe drought particularly in years 1995, 1999, 2005, and 2012 with SPI values ranging from -1.51 to -1.59 . Some other rainfall stations such as Baqura, Ibbin, Khanasiri, Kharja, Mafraq police, Ramtha, 
Turra, and Umm Qais have also suffered several periods of drought mostly in 1993.

\section{Percent Departure from Normal rainfall Index}

The results of this index show no significant difference between the long-term mean rainfalls of 20 years (1993-2013). Figures 4 and 5 show the original PDN and modified PDN values and distribution.

Using the original PDN, extreme drought event was shown only in 1993, while severe drought events occurred in large scale in 1995, 1999, and 2001 and in limited areas in 1996 and 2005. Instead, in other years, the drought index ranged from moderate to mild drought, and there was "no drought" event category in 1994, 1997, 2009, 2012, and 2013. Instead, application of the modified PDN resulted in an increase in the years with extreme drought events to include 1993, 1995, and 1999 in large scale, while limited scale of extreme drought index occurred in 2005 and 2006. Severe drought category occurred in 1995, 1996, 1999, 2005, and 2006. In other years, the drought index ranged from moderate to mild drought, and there was "no drought" event category in 1994, 1997, 2002, 2009, 2012, and 2013.

\section{Hydrological drought}

The study has shown that a decline of water level takes place in various wells within the study area during the period of 1993-2014. During most years, major parts of the YB region experienced water stress events despite of wet year events in SPI and high rainfall amounts. For instance, 2002 and 2003 were very wet years in SPI but show extremely dry events in SWI, and other years in most of the targeted area represent stress water years with extremely and severe drought years apart from 1998, which reflects mild drought within most of the study area as shown in Fig. 4. The SWI results show the highest extreme drought events in 2001 in Souf well, while other extreme drought periods were observed at Wadi Elyabis well in 1994 and at Mafraq well in 1995. As compared to SPI maps, our SWI maps reflect severe and extreme drought events in most years; thus, this represents the harm that affects the groundwater levels in the study area.

Figure 6 shows that the years 1994, 1995, 1996, 2003, 2005, 2009, 2012, and 2014 are 100\% dry areas according to the SWI, while the years 2005, 2006, 2007, 2008, 2009, 2010, and 2011 are $100 \%$ dry areas according to the SPI (Fig. 7).

\section{Discussion and conclusions}

The YB is an important area in Jordan because of the high population density and of the presence of most of the green areas. Most of the water supply in the area comes from groundwater resources; hence, groundwater recharge is very important in the water budget for the basin to achieve sustainable management.

This article found that climatic changes are negatively impacting the YB because of the changing rainfall patterns and in the decreased amount of these precipitations. Consequently, there is an increasing abstraction of the groundwater resources in order to match the needs of the growing population and uses, negatively impacting the groundwater recharge. Finally, the article also showed that the relation between different drought indices is affected by the natural conditions, especially the relation between the SPI and SWI.

More specifically, the article showed that the hydrological index SWI reflects much more extreme drought events than the meteorological indices. In fact, this index is associated with the variation and decreasing in rainfall amounts in addition to the increasing groundwater abstraction. Other trends that have been registered by this study are the decreasing in discharge rates of springs within the targeted area; the lowering of the groundwater table levels which is shown in the SWI maps; and the deterioration of groundwater quality through the increasing of the salinity of the groundwater.

Acknowledgements Thanks are due to the Ministry of Water and Irrigation, Government of Hashemite Kingdom of Jordan, for supporting with data and records from its archive.

Open Access This article is distributed under the terms of the Creative Commons Attribution 4.0 International License (http:// creativecommons.org/licenses/by/4.0/), which permits unrestricted use, distribution, and reproduction in any medium, provided you give appropriate credit to the original author(s) and the source, provide a link to the Creative Commons license, and indicate if changes were made.

\section{References}

Awawdeh MM, Jaradat RA (2010) Evaluation of aquifers vulnerability to contamination in the Yarmouk River basin, Jordan, based on DRASTIC methodArab J Geosci 3: 273. doi:https://doi.org/10. 1007/s12517-009-0074-9, 282

Al-Dardoor AH, Al Taani AT, Hammouri NA (2013) Drought assessment using advanced GIS and remote sensing techniques: a case study of Yarmouk River Basin, unpublished Master thesis. https://search. mandumah.com/Record/718603

Bohling G (2005) Kriging:http://people.ku.edu/ gbohling/cpe940/ Kriging.pdf

Bhuiyan C (2004) Various drought indices for monitoring drought condition in Aravalli terrain of India. In: Proceedings of the XXth ISPRS Conference. Int. Soc. Photogramm. Remote Sens, Istanbul Available at: http://www.isprs.org/istanbul2004/comm7/papers/243. pdf

Bhuiyan C, Singh RP, Kogan FN (2006) Monitoring drought dynamics in the Aravalli region (India) using different indices based on ground and remote sensing data. Int J Appl Earth Obs Geoinf 8:289-302

Bandyopadhyay N, Bhuiyan C, Saha AK (2016) Heat waves, temperature extremes and their impacts on monsoon rainfall and meteorological 
drought in Gujarat, India. Nat Hazards 82(1):367-388. https://doi. org/10.1007/s11069-016-2205-4

Dracup JA, Lee KS, Paulson EG (1980) On the definition of droughts. Water Resour Res 16(2):297-302

Edwards DC and McKee TB (1997) Characteristics of 20th century drought in the United States at multiple time scales. In: Atmospheric Science Paper, 634, p. 1-30

Guttman NB (1998) Comparing the palmer drought index and the standardized precipitation index. JAWRA J Am Water Resour Assoc 34(1):113-121

Guttman NB (1999) Accepting the standardized precipitation index: a calculation algorithm. JAWRA J Am Water Resour Assoc 35(2): $311-322$

Holman P (2006) Climate change impacts on groundwater recharge uncertainty, shortcomings, and the way forward? Hydrogeol J 14:637647

Haddadin MJ (Ed.). (2006). Water resources in Jordan: evolving policies for development, the environment, and conflict resolution. Resources for the Future

Hussein H (2016) An analysis of the discourse of water scarcity and hydropolitical dynamics in the case of Jordan. Doctoral dissertation, University of East Anglia

Hussein H (2017a) Politics of the Dead Sea canal: a historical review of the evolving discourses, interests, and plans. Water Int 42(5):527542. https://doi.org/10.1080/02508060.2017.1344817

Hussein H (2017b) A critique of water scarcity discourses in educational policy and textbooks in Jordan. J Environ Educ 1-12. https://doi. org/10.1080/00958964.2017.1373620

Hussein H (2017c) Whose 'reality'? Discourses and hydropolitics along the Yarmouk River. Contemporary Levant 2(2):103-115. https://doi. org/10.1080/20581831.2017.1379493

Hussein H (2018a) The Guarani aquifer system, highly present but not high profile: a hydropolitical analysis of transboundary groundwater governance. Environ Sci Policy 83:54-62. https://doi.org/10.1016/j. envsci.2018.02.005

Hussein H (2018b) Yarmouk, Jordan, and Disi basins: examining the impact of the discourse of water scarcity in Jordan on transboundary water governance. Mediterranean Polit:1-21. https://doi.org/10. 1080/13629395.2017.1418941

Hussein H and Grandi M (2015). Contexts matter: a hydropolitical analysis of Blue Nile and Yarmouk River basins. Social water studies in the Arab Region, 159-178

Hussein H, Grandi M (2017) Dynamic political contexts and power asymmetries: the cases of the Blue Nile and the Yarmouk Rivers. Int Environ Agreements: Politics, Law and Economics 17:795-814. https://doi.org/10.1007/s10784-017-9364-y

IMD (1971) Climate diagnostic bulletin of India_-June, July, August, report no 88, 89 and 90. National Climate Center, India Meteorological Division, Pune

Jasem A, Raggad M (2010) Assessing groundwater vulnerability in Azraq basin area by a modified DRASTIC index J. Water Resource and Protection, 2010, 2, 944-951doi:https://doi.org/10. 4236/jwarp.2010.211112 (http://www.SciRP.org/journal/jwarp)
Jain SK, Keshri R, Goswami A, Sarkar A (2010) Application of meteorological and vegetation indices for evaluation of drought impact: a case study for Rajasthan, India. Nat Hazards 54:643-656

Jones R, Chiew F, Boughton W, Zhang L (2005) Estimating the sensitivity of mean annual runoff to climate change using selected hydrological models. Adv Water Resour 29:1419-1429

Kam T (1995) Integrating GIS and remote sensing techniques for urban land-cover and landuse analysis. Geocarto Intern 10:39-49

Kogan FN (1990) Remote sensing of weather impacts on vegetation in non-homogeneous areas. Int J Remote Sens 11(8):1405-1419

McKee TB, Doesken NJ and Kleist J (1993) The relationship of drought frequency and duration to time scales, Preprints, 8th conference on applied climatology, January 17 22, Anaheim, California, pp 179183

McKee TB, Doesken NJ, Kleist J, (1995) Drought monitoring with multiple time scales. In: Paper presented at 9th Conference on Applied Climatology. American Meteorological Society, Dallas, TX, pp. 233-236

Mishra AK, Singh VP (2010) A review of drought concepts. J Hydrol 391:202-216

Mohammad AH, Almomani T, Alhejoj I (2015) Groundwater vulnerability for the surface outcropping aquifers in Jordan. J Environ Prot 6: 250-258. https://doi.org/10.4236/jep.2015.63025

Palmer WC (1965) Meteorological drought, vol 30. US Department of Commerce, Weather Bureau, Washington, DC

Palmer WC (1968) Keeping track of crop moisture conditions, nationwide: the new crop moisture index

Rossi G (2000) Drought mitigation measures: a comprehensive frame work. In: Voght J, Somma F (eds) In Drought and drought mitigation in Europe. Kluwer Academic Publishers, Dordrecht

Salameh E, Bannayan H (1993) Water resources of Jordan — present status and future potentials. Friedrich Ebert Stiftung, Amman

Shafer BA, Dezman LE (1982) Development of surface water supply index-a drought severity indicator for Colorado. InProc. Western Snow Conference (pp. 164-175)

Shamsnia SA, Amiri SN, Pirmoradian N (2009) Drought simulation in Fars province using standardized precipitation index and time series analysis (ARIMA model). Int J Appl Math 22(6):869-878

Singh RP, Roy S, Kogan FN (2003) Vegetation and temperature condition indices from NOAA AVHRR data for drought monitoring over India. Int J Remote Sens 24:4393-4402

Umran Komuscu A (1999) Using the SPI to analyze spatial and temporal patterns of drought in Turkey. Drought Netw News (1994-2001):49

Wilhite D, Sivakumar M and Wood D (2000) Early warning systems for drought preparedness and drought management. Proceedings of an Expert Group Meeting, 5-7 Sep, Lisbon, Portugal.WMO TD no. 1037

Yorke V (2016) Jordan's shadow state and water management: prospects for water security will depend on politics and regional cooperation. In Society-Water-Technology (pp. 227-251). Springer International Publishing 